Krehul Yuriy, $\mathrm{PhD}$ (Law Sciences), Professor, Head of the Department of General Law Disciplines Kyiv National University of Trade and Economics, 19, Kyoto str., Kyiv, 02156, Ukraine ORCID: 0000-0001-8355-7899

Sukhatskyi Roman, $\mathrm{PhD}$ (Historical Science), Associate Professor, Kyiv National University of Trade and Economics, 19, Kyoto str., Kyiv, 02156, Ukraine

ORCID: 0000-0002-6540-1839

Otamas Inna, $\mathrm{PhD}$ (Historical Science), Head of the Department of Scientific Work State Higher Educational Institution «University of educational management» of National Academy of Educational Sciences of Ukraine, 52 A, Sichovykh Striltsiv Str., Kyiv, 04053, Ukraine ORCID: 0000-0002-3098-2274

\title{
AUDIT AS AN ITEGRAL PART OF BUSINESS SECURITY ENSURING: ORGANIZATIONAL AND LEGAL ASPECT
}

The analysis of audit in the field of entrepreneurship from the point of view of its influence over business security ensuring is performed in the article. The organizational and legal aspects of conducting audit control as a means of security and the method of enterprise's competitiveness strengthening in order to ensure independent conditions of its development are determined.

Based on the performed analysis it was ascertained that there are certain problems of audit activity legal regulation. However, it was shown that the existing issues do not deprive business entities of the possibility to determine correctly the procedure and peculiarities of conducting audit of an enterprise as a part of general business security, as well as of taking necessary security measures while it is performed. The types of audit control were defined and it was grounded that upon applying the provisions of many laws and regulations concerning various aspects of audit, the business owners have the opportunity to use any of them (mandatory, agreed-upon, internal) as a part of business security ensuring and due to this to draw their business up to higher development positions. However, each entrepreneur should 
set the procedures and special aspects of developing such security measures at his own discretion within the scopes of the legislation in force.

In the process of analysis the exact scope of rights and opportunities that an entrepreneur has while each type of audit control is performed and the aspects one should pay attention to in order to use audit as a part of business security ensuring considering real or potential threats to his business were determined.

Keywords: audit, laws and regulations, legal regulation, entrepreneurship, business security.

Крегул Юрій, Сухацький Роман, Отамас Інна. Аудит як інтегральна частина забезпечення безпеки бізнесу: організаційний та правовий аспект.

У статті проводиться аналіз аудиту в сфері підприємництва з позицій його впливу на забезпечення безпеки бізнесу. Визначаються організачійноправові особливості проведення аудиторського контролю як заходу безпеки та способу посилення конкурентоспроможності підприємства $з$ метою забезпечення належних умов його розвитку.

На основі проведеного аналізу з'ясовано, щзо існують певні проблеми правового регулювання аудиторської діяльності. Однак показано, що існуючі проблеми не позбавляють суб'єктів господарювання можливості правильно визначити порядок та особливості проведення аудиту на підприємстві як складової загальної безпеки бізнесу, а також прийняти необхідні заходи захисту під час його здійснення. Визначено різновиди аудиторського контролю та обгрунтовано, щз застосовуючи положення багатьох нормативно-правових актів, які регулюють різні аспекти аудиту, власники підприємств мають можливість використовувати будь-який з них (обов'язковий, договірний, внутрішній) як складову забезпечення безпеки бізнесу та за рахунок иього підіймати його на більш високі позищії розвитку. Проте кожен підприємець у межах чинного законодавства повинен на власний розсуд визначати порядок та особливості побудови таких заходів економічної безпеки.

У прочесі аналізу встановлено, яким саме обсягом прав та можливостей володіє підприємеиь під час проведення кожного із різновидів аудиторського контролю, та на які саме аспекти варто звертати увагу з метою використання аудиту як складової забезпечення безпеки бізнесу з огляду на реальні чи потенційні загрози для власного підприємства.

Ключові слова: аудит, закони та нормативно-правові акти, правове регулювання, підприємництво, безпека бізнесу.

Relevance of the research topic. Ukraine's transfer to market economy under conditions of independence caused rapid development of entrepreneurship. At the same time appearance of a large amount of small, medium and large business entities caused high level of competition and business owners' attempts to strengthen their positions at the market. 
Due to these changes, the necessity to implement audit as a new form of financial and economic control has appeared. According to articles 1 and 363 of the Law of Ukraine «On Audit of Financial Reporting and Auditing» No. 2258-VIII dated 01.10 .2018 , audit of financial reporting is an auditing service to verify accounting records and financial statements and / or consolidated financial statements of a legal entity, a representative office of a foreign entity or another entity that submits financial statements and consolidated financial statements to express an independent opinion of the auditor on its compliance in all material respects with the requirements of national accounting regulations (standards), international financial standards or other requirements [13].

However, at the beginning of its formation audit was only a means of examination and confirmation of accounting documents and statements but in modern conditions it has acquired the new features. Namely such as consulting orientation and prevention of risks in the enterprises' activity, forecasting their economic activity and providing business entities with a wide range of consulting and expert services. Thus, audit should be considered as an integral part of ensuring business activity safety which has certain specificity.

Analysis of recent researches and publications. It should be mentioned that there are many studies of native and foreign scientists devoted to the matters of audit. However, their studies were focused on consideration of legal grounds of performing auditing practice in various fields of business activity. The mutual publication of $\mathrm{Yu}$. V. Velykyi, Ye. H. Yurin [18] and the studies of O. S. Horiaieva [7], L. L. Kinashchuk [10], A. O. Semenets [12], A. M. Chorna [3] and others are such works. Some scientists, such as O. V. Tsarenko [15], L. Yu. Ilnytska [8], A. O. Saiun [11], set the goal to study and compare the laws and regulations on audit of different states aiming to provide recommendations concerning introduction of possible amendments to the internal national legislation. Also, there is quite an interesting study of M. I. Kamlyk «Economic security of business activity» [9] and in one of its chapters the author considers audit as a form of independent financial and economic control.

However, the scholars of various aspects of audit did not regard it as one of the parts of business security ensuring. As well as they did not pay attention to defining and applying the security means for its appropriate performance and ensuring further protection of the interests of an enterprise.

Formulation of the problem. Thus, the purpose of this study is to determine the peculiarities of performing audit at commercial enterprises as one of the means of ensuring business security, as well as to choose the ways of protecting an enterprise's interests from the auditors' illegal actions.

Analysis of recent research and publications. Considering audit as an integral part of business security formation it is important to understand the tasks of audit activity established at the legislative level and those the business owner may and should set taking care of protection of his business. 
Hence, taking into account the above mentioned article 1 and article 8 of the Law «On Audit of Financial Reporting and Auditing» and the practice of performing audit control at enterprises, the main tasks are as follows:

- examination of truthfulness of financial statements, legality and expedience of business transactions, and state of accounting;

- performing analysis of financial and economic activity with the aim to determine the ways of increasing its economic effectiveness;

- consulting business activity units regarding arrangement of accounting and internal financial control, taxes, improvement of the methods of management;

- performing evaluation of the enterprises' property in view of their privatization, bankruptcy, etc.;

- protection of the client's financial interests;

- conducting the scientific researches in the fields of organization and methodology of accounting, management, financial control;

- developing based on a contractual basis the projects, expert conclusions and other materials connected with creation of new and reorganization of the active enterprises [13].

Thus, the efforts of auditors are directed towards the study of economic, organizational and informational characteristics of the business entities. This means that all the components of business activity, each having a specific functional meaning for functioning capacity of such unit, are considered as the object of audit analysis. They include: material, labour and financial resources; business processes; economic results of business activity; organizational forms, methods and functions of management $[9$, p. 140].

However, solving such tasks at a high level requires the presence of a clear and structured legislative support. In Ukraine the above mentioned law «On Audit Activity» is the legal basis of determination of all the actions related to "audit» as a term. Thus, setting the goal and tasks of audit, the principles of its organization, preparation of auditor's report and other issues are to be grounded based on its provisions.

It should also be noted that in many aspects the audit activity in Ukraine is imitation of the same activity abroad. Thus, by the decision of the Chamber of Auditors of Ukraine dated 30.11.2006 the obligatory application of the International Standards on Auditing by the entities performing audit was established since 01.01.2007. However, neither the mentioned laws and regulations, nor the State Standards on Auditing [8, p. 167; 11, p. 105] issued under the guidance of the Controller General (US Government Accountability Office), the International Standards of Internal Audit of the Institute of Internal Auditors, the Guiding Principles for Evaluators of the Joint Committee on Evaluation Standards, the Standards on Educational and Professional Testing, which are also the source of auditing activity in Ukraine, contain the common understanding of the terms «audit» and «auditor». But, 
taking into account the provisions of the national rules of law, the international experience and the needs of business entities one may say that there is every reason to regard audit in the sphere of business as an independent examination of the impartial economic activity data and events and their compliance with the established criteria with further providing of results to the interested parties in the way established by law. This confirms the significance of audit as a method of business risks decreasing.

Also, unlike ordinary analysis of business activity and financial control, audit uses the methods of comprehensive assessment and comparison to understand the key aspects of business processes. The auditing activity focuses mainly on increasing the business management efficiency and internal control in the first place. The highquality realization of these processes will ensure determination of the ways of increasing effectiveness of the business entities' activity.

Upon developing the strategy of business protection from various real and potential threats using audit control of an enterprise's business activity, one should remember that by its organizational features it is classified as mandatory, agreed-upon and internal. Respectively, each of them has its own organizational and legal peculiarities of being performed, its functional peculiar features of influencing the business economic security and the probable measures of protecting business interests upon conducting audit control [9, p. 139-141].

The mandatory audit is regulated by the respective legislative documents and laws. The categories of entrepreneurs, subject to audit examination, and the grounds of such examination are determined by them. According to article 36 of the law «On Audit of Financial Reporting and Auditing» conducting of audit is obligatory for:

- confirmation of the truthfulness and completeness of annual and consolidated financial statements of public joint-stock companies, enterprises issuing bonds, professional participants of stock market, financial institutions and other business units whose statements are subject to official public disclosure according to the legislation of Ukraine, except for institutes and organizations fully supported at the expense of the state budget;

- examination of financial position of the founders of banks, foreign investment enterprises, public joint-stock companies (except for individuals), insurance and holding companies, joint investment institutes, trusts and other financial intermediaries;

- issuers of securities, dealing with public placement of shares and derivatives, as well as upon receiving the license for professional activity on securities market;

- other cases provided for by the legislation [13].

Unlike mandatory the agreed-upon audit is performed based on the concluded agreement between the business unit and an auditing company. The object of audit, scope of work, period and time-frame of examination are stipulated in the agreement.

On a contractual basis the auditing company may provide the customer with services on improving accounting and financial control, consultations and 
recommendations regarding business activity and other related services. However, despite the fact that audit is performed an a voluntary basis, the business owner is to make a decision on annual enterprise's report approval and in case of negative report of the auditor regarding truthfulness of the annual report he is to eliminate the revealed drawbacks and to submit the revised report for additional checking. One should also remember that in case of failure to submit or late submission of the audit report to the tax authority because of the business unit's fault, financial sanctions and administrative fines provided for by the effective laws and regulations of Ukraine are to be applied to the enterprise, which in its turn will have negative effect on the enterprise's business activity [7, p. 135-136; 9, p. 141-142].

It should also be remembered that according to article 7 p. 4 of the Law «On Audit of Financial Reporting and Auditing» the business entity's authorities are obliged to provide the auditor (auditing company) with the conditions for high-quality performance of audit and are as well responsible for the fullness and truthfulness of the information and documents given to the auditor (auditing company) for conducting audit or providing other audit services [13].

Thus, the applied measures will give the enterprise an opportunity to avoid imposing various fines by the control authorities, as well as, to a certain extent, protect the enterprise from undesirable financial losses disrupting its economic stability and being additional burden in the business unit's cost of goods or services sold.

Internal audit has a special significance for business security ensuring. It is performed by the business owner with the aim to determine managerial needs, to ensure enterprise's solvency and to prevent bankruptcy. With the help of internal audit the issues regarding increase of the company's efficiency and profitability by means of using its own resources and applying the know-how, scientific assessment and reasoning of business activity in general or a separate business transactions may be solved [12, p. 147, 151]. Thus, internal audit may be considered as an integral part of the system of managerial control and is able to perform preventive and strategic functions in the course of enterprise's business activity. It allows to avoid appearing of conflict situations in future, as well as to work out the recommendations for improving the company's marketing activity. Internal audit is directed towards supporting managers in performing their controlling functions, while the external audit is useful for the outside groups.

For the security purposes the important task for the business owners is to transform it into current audit which will be performed in order to provide the enterprise's management with the necessary information for making managerial decisions regarding augmentation of the products and services competitiveness, strengthening business' financial stability, etc. [9, p. 142-143; 18, p. 54-55].

Protection of business' interests in the course of conducting audit is also an important issue. For this purpose it is important to realize clearly the position of each of the participants of legal relationship while performing audit of the enterprise. 
Thus, according to articles $7-11$ of the Law «On Audit of Financial Reporting and Auditing», regardless of the form of audit - mandatory, agreed-upon or internal, the auditing company and an auditor are obliged:

- to stick in auditing activity to the requirements of the laws and regulations regarding audit activity, standards of audit, auditors' principles of independence and the respective decisions of the Audit Chamber of Ukraine;

- to perform audit and to provide other audit services in a proper way;

- to inform the business owners, authorized by them persons or customers of the revealed in the course of audit shortcomings of accounting and preparation of financial statements;

- to keep in secret the information received upon conducting audit and performing other audit services, do not disclose the data being a commercial secret and do not use them in one's own interests or for the benefit of the third parties;

- to be responsible to the customer for breach of the agreement terms according to the agreement and law;

- to confine their activities to performing audit and other types of works related directly to rendering audit services in the form of consultations, inspections and expert examinations;

- to submit in due time the report regarding their audit activity to the Audit Chamber of Ukraine [13].

The terms of appearance of legal responsibility for violation by auditing companies and auditors of their obligations are stipulated in the Law of Ukraine «On Audit of Financial Reporting and Auditing», in the Code of Ukraine on Administrative Infringements, in Civil and Criminal Codes and in other laws and regulations. However, taking into account the mentioned above obligations, in order to ensure their business' security the business owners should specify in the regulatory documents, which will determine the procedure of performing auditing activity at the enterprise, the peculiarities of the auditor's and auditing company's legal responsibility. These may include: instructions of the controlling authorities, agreements, contracts for performing audit, orders of the enterprises' directors on appointment of the responsible for conducting the internal audit persons or the persons responsible for ensuring the required conditions and for coordination of the internal auditors' actions. Thus, for example, in the agreements and internal orders the owners should make provision for providing information with limited access and the way it is to be used at the enterprise, especially the information which is a commercial secret [9, p. 145; 7, p. 171-181].

This relates to a large extent to the fact that the question of how the information of the enterprises' activity should be structured into different types, including commercial secret, and in which way it is to be used is not defined clearly in the legislative documents. In particular, according to article 505 of the Civil Code of Ukraine the commercial secret is a variety of information which is a secret in general or in its certain form or the complex of its parts, which is not known and is not easily 
accessible to people who usually deal with the type of information it is related to, and due to this it has a commercial value and was a subject of adequate to existing circumstances measures of keeping it in secret, taken by a person who controls it on a legal basis. According to point 2 of the same article the commercial secret may be the information of technical, organizational, commercial, industrial or other character, except for the information which cannot be related to commercial secret according to the law [2].

In addition to these, article 420 of the Civil Code of Ukraine (CCU) [2] and article 155 of the Commercial Code of Ukraine [4] state that commercial secret is an object of intellectual property, and article 506 of CCU gives the opportunity to the business entities to determine the range of intellectual property rights to commercial secret. The following rights should be related to them: the right to use commercial secret; the exclusive right to permit using the commercial secret; the exclusive right to prevent illegal disclosure, collection or use of commercial secret; other intellectual property rights set forth by the law [2].

It is important to emphasize: the analysis of the effective legislation of Ukraine showed that the structure and volume of data which is a commercial secret and the way it is protected are determined by the owner himself following the legislation in force [17, p. 312-313]. Since any information may be a commercial secret, except for the data set forth in part 4 of article 30 of the Law of Ukraine «On Information» [5] and the Decree of the Cabinet of Ministers of Ukraine No 611 [14] «On the List of Information which is not a Commercial Secret». And the legal basis for requesting to perform certain actions or refrain from performing them with regard to the information with limited access is the right of ownership to this information [1, p. 182-184].

From their part such security measures will create additional restraining factors to possible illegal actions from the auditor's part in the form of illegal use or disclosure of enterprise's commercial secret. Thus, one should remember that the main purpose of the developed measures of enterprises' interests protection, including the security of information whilst performing audit, should not be oriented the reimbursement of damage caused by the loss of commercial secret, but to prevention of such loss.

It should be remembered that the subject of encroachment on the important for the enterprise's activity information may be not only persons performing internal or agreed-upon audit, but also those performing mandatory audit control. As the representatives of controlling authorities, using their official position, may perform such actions for their self-interest. For example, on the competitors' order [1, p. 184]. Thus, for better protection in the course of audit control of information that is a commercial secret from the illegal actions of controlling authorities the business entities should use the provisions of the Decree of the President of Ukraine No 817/98 dated 23.07.1998 [6] and the Order of the State Committee of Ukraine on the Development of Entrepreneurship No 18 dated 10.08.1998 [16]. These regulations 
permit in a set order not to admit the representatives of the controlling authorities to perform inspections and to restrict their access to the certain types of information, including the commercial secret.

Conclusion. Thus, taking into account the tendencies of development of entrepreneurship in Ukraine such additional measures of business security ensuring in the course of audit are still relevant.

By summing up the mentioned above, it must be said that the existing set of laws and regulations of native and foreign origin contains certain discrepancies in understanding of audit activity. Although, the study of its functional aspects and the questions regarding formation of complex protection of business activity provided grounds to consider audit as an integral part of business security ensuring.

The study showed that the audit control, under the conditions of high-quality approach to its performance, plays an important role in business security ensuring. As the comprehensive understanding of the qualitative characteristics of audit and correctness of performing and applying it ensure the possibility to detect the shortcomings in the enterprise's activity and to determine the ways to increase business efficiency and profitability by means of using its own resources.

In addition, based on the said above it should be mentioned that in order to improve the effectiveness of performing audit control and to provide proper conditions for development of entrepreneurship it is necessary to pay attention to the existing problems in this sphere in order to solve them.

\section{REFERENCES}

1. Bondarchuk Yu. V., Maryshchak A. I. Business security: organizational and legal basis: study guide. K. : Vydavnychyi dim: «Skif», KNT, 2008. 372 p.

2. Civil Code of Ukraine No 435-IV dated 16.01.2003 with amendments: http: //www. rada.gov.ua/laws/show/435-15.

3. Chorna A. M. Legal regulation of audit financial control in Ukraine: monography. H. : NikaNova, 2013. 196 p.

4. Commercial Code of Ukraine No 436-IV dated 16.01 .2003 with amendments: http: //www. rada.gov.ua/laws/show/436-15.

5. Decree of the Cabinet of Ministers of Ukraine «On the List of Information which is not a Commercial Secret» No 611 dated 09.08.1993: http: //www. rada.gov.ua/laws/show/611-93.

6. Decree of the President of Ukraine «On Certain Measures of Business Activity Deregulations» No 817/98 dated 23.07.1998: http://www.rada.gov.ua/ laws/show/817/98.

7. Horiaieva O. S. Legal regulation of the audit activity in Ukraine. Kyiv : Yurydychnyi svit, 2014. 224 p. 
8. Ilnytska L. Yu. Actual problems of regulation of audit activity under the conditions of transfer to international standards. Naukovyi visnyk of Uzhhorod National University. 2015. Series «Pravo». Issue 30. T. 1. P. 167-169.

9. Kamlyk M. I. Economic security of business activity. Economic and legal aspect: study guide. K. : Atika, 2005. 432 p.

10. Kinashchuk L. L. Audit activity in the system of financial control: organizational and legal aspects: monograph. Kyiv : Academy of Municipal Management. 2015. 388 p.

11. Saiun A. O. Problems of legislative regulation of audit activity. Oblik i audit. Finansovyi prostir. No 2 (2). 2011. P. 104-109.

12. Semenets A. O. Organization of internal audit of products sales. Visnyk NTU «HPI». 2013. No 52 (1025). P. 140-145.

13. The Law of Ukraine "On Audit of Financial Reporting and Auditing» No. 2258-VIII dated 01.10.2018: https://zakon.rada.gov.ua/laws/show/2258-19.

14. The Law of Ukraine «On Information» No 2657-XII dated 02.10 .1992 with amendmentst : https://zakon.rada.gov.ua/laws/show/2657-12.

15. Tsarenko O. V. Institutional ensuring of the process of state regulation of the trajectory of public audit goal-oriented development. Derzhavne upravlinnia: teoriia ta praktyka (e-scientific publication). - available at : http://www.epatp.academy.gov.ua/2015_1.html.

16. Order of the State Committee of Ukraine on Development of Entrepreneurship «On Establishing the Form and the Way of Keeping the Book of Control Authorities Visits to Business Units (Book of Examinations Registration)» No 18 dated 10.08.1998: http: // www.rada.gov.ua /laws/shoe/z0619-98.

17. Ortynskyi V. L., Kernytskyi I. S., Zhyvko Z. B. and others. Economic security of enterprises, organizations and institutions: study guide (for students of the institutes of higher education). K.: Pravova iednist, 2009. 544 p.

18. Velykyi Yu. V., Yurin Ye. H. Organizational stages of internal audit at an enterprise. Ekonomichna nauka. Investytsii: praktyka ta dosvid No 24/2013. P. 53-55. 